of the impacted safety pin had clearly ceased. Also the pin had caused epigastric pain and a small haemorrhage, and required removal. In view of the previous abnormalities in the right upper abdomen and the patients' cardiac status, laparotomy and duodenotomy would have been technically difficult and of considerable risk to the patient.

Fibre-optic endoscopy has found a number of diagnostic and therapeutic applications in diseases of the upper digestive tract. Although the second part of the duodenum is accessible using the endoscope, the special devices marketed for the removal of foreign bodies were of little use in this case because of the extreme flexion of the tip required. Fortunately, the biopsy forceps fitted the loop of the ingested safety pin and the pin was lying the appropriate way for its retrograde removal. The advantages of endoscopic removal in this case are clear, but the obviation of general anaesthesia, laparotomy, and a period of postoperative recovery apply equally to the fit patient.

If the patient had presented at hospital while the pin was still in the stomach its removal would have been much easier. Ingested foreign bodies that are likely to impact in the bowel should be removed from the stomach as a matter of urgency when endoscopy is to be used.

${ }^{1}$ Equen, M, Annals of Otology, Rhinology and Laryngology, 1963, 72, 991. 2 Fyser, B, Lancet, 1972, 1, 76 .

${ }^{3}$ Gross, R E, The Surgery of Infancy and Childhood. Philadelphia, W B Saunders, 1953.

Department of Surgery, Royal Victoria Infirmary, Newcastle upon Tyne NE1 4LP

M H THOMPSON, MB, FRCS, honorary senior registrar

\section{Oestrogen and androgen receptors in breast cancer and response to endocrine therapy}

We have treated 51 cases of breast cancer with endocrine therapy since 1973, when we began to assay androgen (DHT) receptor in the tumour. The response to treatment in these cases has been studied to evaluate the clinical significance of the presence of the receptor.

\section{Patients, methods, and results}

Cytosols of the tumour tissues were prepared as recommended at the EORTC workshop in $1972 .^{1}$ Oestrogen $\left(\mathrm{E}_{2}\right)$ receptor and DHT receptor in the cytosol were measured by Wagner's method ${ }^{2}$ using agar gel electrophoresis. Incubation with the labelled hormone was continued for about 16 hours. The binding of $E_{2}$ or DHT was expressed as $\mathrm{cpm} / \mathrm{g}$ tissue protein (counting efficiency $45^{\circ}{ }_{1}^{\prime}$ ).

All the patients had progressive advanced breast cancer and were selected, investigated, treated, and evaluated according to strict criteria. ${ }^{3}$ Receptorpositive, receptor-negative, and intermediate tumours were distinguished by statistical evaluation of the hormone-binding capacities of benign and malignant tumours. The procedure for $\mathrm{E}_{2}$ receptors has previously been described. ${ }^{3}$ A similar procedure was followed for DHT receptors. Intermediate DHT receptor values were regarded as positive.

$\mathrm{E}_{2}$ and DHT receptors were found with about equal frequency but were apparently independent in distribution. The table shows the results of treatment with oestrogens or by castration in the 51 patients. The presence of $E_{2}$ receptor had a significant predictive value for response to ethinyl-

Correlation of response to presence of $E_{2}$ or DHT receptor, or both

\begin{tabular}{|c|c|c|c|c|c|}
\hline \multirow{2}{*}{ Treatment } & & \multirow{2}{*}{ Receptors present } & \multicolumn{3}{|c|}{ No of patients } \\
\hline & & & Responding & $\begin{array}{l}\text { Not } \\
\text { responding }\end{array}$ & Total \\
\hline Castration $\quad \ldots$ & . & $\begin{array}{l}\mathrm{E}_{2} \text { and DHT } \\
\text { Only E } \\
\text { Only DHT } \\
\text { No receptor }\end{array}$ & $\begin{array}{l}1 \\
0 \\
3 \\
0\end{array}$ & $\begin{array}{r}1 \\
1 \\
1 \\
12\end{array}$ & $\begin{array}{r}2 \\
1 \\
4 \\
12\end{array}$ \\
\hline Ethinyloestradiol & . & $\begin{array}{l}\mathrm{E}_{2} \text { and DHT } \\
\text { Only E: } \\
\text { O.ly DHT } \\
\text { No receptor }\end{array}$ & $\begin{array}{l}6 \\
7 \\
1 \\
1\end{array}$ & $\begin{array}{l}1 \\
2 \\
6 \\
8\end{array}$ & $\begin{array}{l}7 \\
9 \\
7 \\
9\end{array}$ \\
\hline
\end{tabular}

oestradiol but the presence of DHT receptor did not. There was a significant correlation between response to castration and presence of DHT receptor (no response in 13 patients without DHT receptor, 4 remissions in 6 patients with DHT receptor; $P=0.004$ )

\section{Discussion}

The results in our small series of patients confirm the importance of $E_{2}$ receptor in relation to oestrogen therapy in cases of postmenopausal breast cancer. Our findings are in addition to those we presented at the National Cancer Institute Workshop in $1974 .^{3}$ The results also indicate that DHT receptor may be an important factor in the response to castration in premenopausal patients.

Determination of receptors for hormones other than oestrogens may help to gain a better understanding of the hormone responsiveness of breast cancer. Determination of both $\mathrm{E}_{2}$ and DHT receptors seems to give a more accurate prediction of response to castration; absence of both receptors predicts a very poor response.

We thank Mrs A C M Brakeboer and Miss M Veen for their skilled help. This work was supported by the Maurits and Anna de Kock Fund.

1 EORTC Breast Cancer Co-operative Group, European fournal of Cancer, $1973,9,379$.

Wagner, R K, Hoppe-Seylers Zeitschrift für Physiologische Chemie, 1972, 353, 1235.

${ }^{3}$ Korsten, C B, Engelsman, E, and Persijn, J P, Estrogen Receptors in Human Breast Cancer, ed W L McGuire, P P Carbone, and E P Volmer, p 93. New York, Raven Press, 1975.

Departments of Clinical Chemistry and of Internal Medicine, Netherlands Cancer Institute, Antoni van Leeuwenhoek Zieken-

huis, Amsterdam, Netherlands

J P PERSIJN, PHD, clinical chemist

C B KORSTEN, PHD, clinical chemist

E ENGELSMAN, MD, internist

\section{Hypokalaemic periodic paralysis complicating thyrotoxicosis}

Periodic paralysis associated with thyrotoxicosis is rare, most cases having been reported from Japan. ${ }^{1}$ This is the first case of thyrotoxic periodic paralysis to be reported from Britain.

\section{Case report}

A 30-year-old Scottish man was referred because of weight loss, palpitations, tremulousness, sweating, and heat intolerance over the previous 18 months. Over the previous year he had also experienced about 25 attacks of episodic weakness of the legs, which had been labelled as "functional." The attacks usually occurred half-an-hour after he awoke, but could also come on at any time of the day, and always when he was awake, each attack lasting from 2 to 37 hours. Sometimes when he felt his legs stiffening he learnt that he could usually "work off" an impending attack by walking around for 20 minutes. The attacks bore no relation to exercise, carbohydrate content of meals, alcohol, emotional upsets, or cold. ${ }^{2}$ During the attacks there was no sphincter disturbance, and often he had to be taken to the lavatory to defaecate or micturate. He had no pain or sensory disturbance, and between the attacks of paralysis no residual weakness. The attacks did not follow a period of prolonged rest, as he experienced episodic weakness after sitting for only ten minutes. There was no family history of periodic paralysis.

He had clinical evidence of thyrotoxicosis, with bilateral exophthalmos, lid lag, and retraction; a diffusely enlarged thyroid gland, with a loud bruit and brisk tendon reflexes. Thyroid function tests confirmed the diagnosis. Two days after admission he collapsed, and examination showed severe bilateral weakness of the legs with a complete flaccid paralysis from the wais down. The reflexes in the legs were absent, and there was no pain or muscle tenderness. His sensorium was intact, and there was no disturbance of phonation, deglutition, or sphincter function. The results of investigations at the time of paralysis showed a serum potassium level of $1.8 \mathrm{mmol} / 1(\mathrm{mEq} / 1)$ ECG showed evidence of hypokalaemia. He recovered completely six hours later, and examination showed no evidence of weakness, brisk tendon 
reflexes, normal serum potassium, and a normal ECG. He experienced two further attacks of paralysis just after starting antithyroid treatment, and on each occasion weakness and hyporeflexia were demonstrated together with hypokalaemia (serum potassium 2.5 and $2.6 \mathrm{mmol} / \mathrm{l}$ ). On each occasion he recovered completely 12 hours later with no treatment, the serum potassium reverting to normal, as did the ECG. Extensive investigations during and between the attacks showed normal results. Treatment with carbimazole and propranolol resulted in weight gain, and, apart from one mild abortive attack, no further episodes of paralysis occurred over the next seven months.

\section{Discussion}

The recurrent episodes of flaccid paralysis, spontaneous recovery, and absence of residual weakness are typical of thyrotoxic periodic paralysis, ${ }^{3}$ attacks of which may also occur without a lowering of serum potassium. Norris ${ }^{4}$ found a poor correlation between the decrease in the serum potassium level and the degree of paralysis, and noted the serum potassium concentration did not rise as the clinical attacks cleared. The only consistent histological finding (on muscle biopsies taken during attacks) in all cases so far studied has been some degree of vacuolation. ${ }^{5}$ Further investigation is needed to determine the pathophysiology of thyrotoxic periodic paralysis, but, probably because of lack of its awareness, not many cases have been reported outside Japan. The present report should alert doctors to its existence (attacks of periodic paralysis may antedate symptoms of thyrotoxicosis), with the hope of discovering similar patients with this treatable and rare complication.

${ }^{1}$ Okinaka, S, ot al, Fournal of Clinical Endocrinology, 1957, 17, 1454.

2 McFadzean, A J S, and Yeung, R, British Medical fournal, 1967, 1, 451.

${ }^{3}$ Ramsay, I, Thyroid Disease and Muscle Dysfunction. London, Heinemann Medical Books, 1974.

${ }^{4}$ Norris, F H, Clarke, E C, and Biglieri, E, fournal of the Neurological Sciences, 1971, 13, 431 .

${ }^{5}$ Schutta, H S, and Armitage, J L, fournal of Neuropathology and Experimental Neurology, 1969, 28, 321.

\section{Non-absorbable cystic duct ligatures and common bile duct calculi}

The use of non-absorbable ligatures on the cystic duct remnant after cholecystectomy is said to expose the patient to the risk of recurrent calculus formation. The following case is a clear example of this complication.

\section{Case report}

In November 1973 a 67-year-old woman was admitted with recurrent cholecystitis and jaundice. At operation a small, chronically inflamed gall bladder containing multiple mixed calculi was removed and the cystic duct remnant secured with a silk ligature. Three large calculi with some debris were extracted from the common bile duct. The choledocotomy was closed over T-tube drainage using extramucosal chromic catgut sutures. Her postoperative recovery was uneventful and a $T$-tube cholangiogram 10 days after operation showed no residual calculi and free flow of contrast medium into the duodenum. An incidental finding during this admission was a macrocytic anaemia due to vitamin $B_{12}$ deficiency, for which she received replacement and maintenance treatment with vitamin $B_{12}$.

She remained well until August 1974, when she began to suffer intermittent attacks of colicky epigastric and subcostal pain, lasting from 15 minutes to 8 hours. Transient jaundice was noted on one occasion. She was well between attacks. Examination on admission was unhelpful; there was no jaundice or signs of liver disease. The erythrocyte sedimentation rate was $99 \mathrm{~mm}$ in one hour, serum bilirubin $24 \mu \mathrm{mol} / 1(1.4 \mathrm{mg} / 100 \mathrm{ml})$, and prothrombin time 18 seconds (control 14 seconds). Other investigations showed nothing abnormal. After admission she had a further attack of pain and tenderness in the right upper quadrant and obstructive jaundice. Investigations showed a serum bilirubin of $123 \mu \mathrm{mol} / 1(7 \cdot 2 \mathrm{mg} / 100 \mathrm{ml})$, alkaline phosphatase of $26 \mathrm{KA}$ units $/ 100 \mathrm{ml}$, and an aspartate transaminase of $266 \mathrm{IU} / 1$. Bilirubin was present in the urine, but there was no excess of urobilinogen. An intravenous cholangiogram performed when the jaundice subsided showed a radiolucent calculus about $1.3 \mathrm{~cm}$ in diameter impacted in the supraduodenal segment of the common bile duct, with proximal dilation of the hepatic ducts.

At laparotomy the calculus was identified in the supraduodenal segment of the dilated common bile duct. A soft granular calculus, about $1 \mathrm{~cm}$ in diameter, was removed. Two tails of black silk were hanging from the calculus and traction on these extracted a black ligature, the knot of which had clearly formed the central nidus of the stone (see fig). There was no debris or further calculus present. A choledochoduodenostomy was performed. Her postoperative course was complicated only by a mild superficial wound infection.

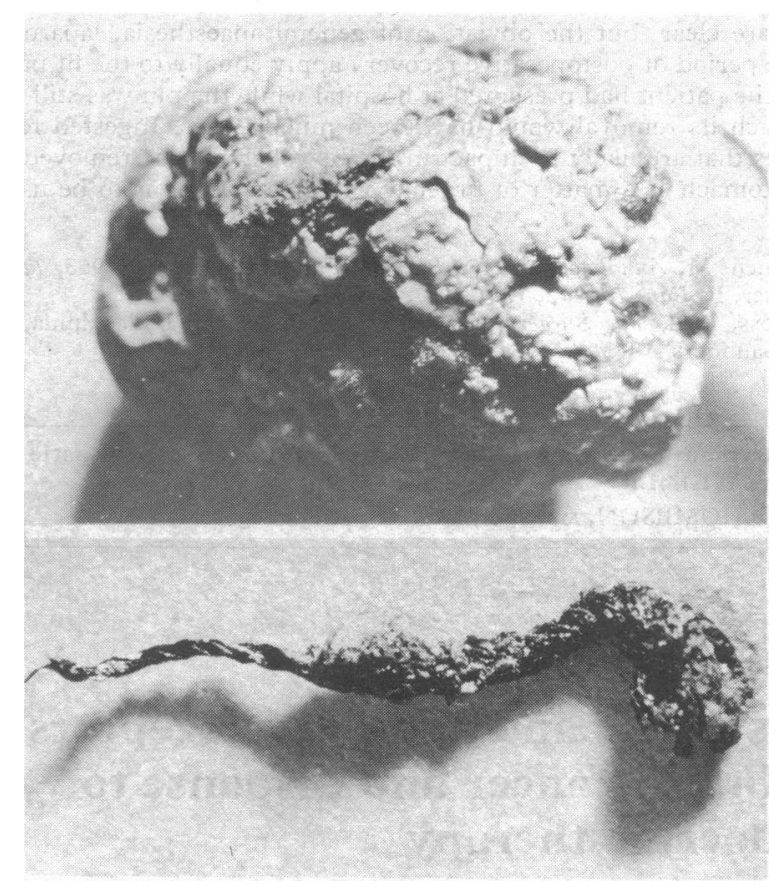

Calculus (top) and black silk ligature (bottom). Knot and proximal half of tails of ligature were included within the calculus.

\section{Comment}

The use of non-absorbable material for cystic duct ligature may lead to further stone formation. ${ }^{1-5}$ How often this occurs is difficult to determine, but there are few reported cases, and the complication seems to be uncommon. Many surgeons feel that absorbable sutures are preferable, but Gunn'2 found that many surgeons in the Manchester region preferred to use non-absorbable cystic duct ligatures because of better tying and knot-holding properties.

Seromuscular silk sutures may be seen at sigmoidoscopy after anterior resection and at gastroscopy after partial gastrectomy. A tight ligature accompanied by local trauma and oedema may lead to necrosis and resorption of the overlying mucosa and also of the tissue included in the ligature, which would then be left unattached and free to move into the lumen or on to the serosal surface as regeneration and repair progress. A ligature through all coats seems more likely to migrate into the lumen than a true seromuscular suture, and a non-absorbable transfixion ligature may also predispose to further calculus formation. Despite the few reports of this complication the use of absorbable material for ligature of the cystic duct remnant is advisable.

1 Ahlberg, A, Acta Chirurgica Scandinavica, 1959, 118, 22

2 Gunn, A, British fournal of Surgery, 1972, 59, 245.

${ }^{3}$ Milbourn, E, Acta Chirurgica Scandinavica, 1949, 99, 285

* Mackie, D B, Haynes, S, and May, R E, British fournal of Surgery, 1973, 60, 23.

${ }^{5}$ Sigler, L, and Sahler, C O, Surgery, 1969, 65, 276.

University Department of Surgery, Queen Elizabeth Hospital, Birmingham B15 2TH

C E NEWMAN, MA, FRCS, lecturer in surgery

J D HAMER, CHM, FRCS, senior lecturer 